\title{
Effects of plant growth promoting rhizobacteria (PGPR) on rooting and root growth of kiwifruit (Actinidia deliciosa) stem cuttings
}

\author{
YASAR ERTURK ${ }^{1}$ SEZAI ERCISLI $^{2 *}$ AYHAN HAZNEDAR $^{3}$ \\ and RAMAZAN CAKMAKCI ${ }^{4}$
}

\footnotetext{
${ }^{1}$ Ispir Hamza Polat Vocational School, Department of Horticulture, 25900, Ispir, Erzurum, Turkey

${ }^{2}$ Department of Horticulture, Faculty of Agriculture, Ataturk University 25240, Erzurum, Turkey

${ }^{3}$ Ministry of Agriculture, Ataturk Tea and Horticulture Research Institute, 55100 Rize, Turkey

${ }^{4}$ Department of Field Crops, Faculty of Agriculture, Ataturk University 25240, Erzurum, Turkey
}

\begin{abstract}
The effects of plant growth promoting rhizobacteria (PGPR) on the rooting and root growth of semi-hardwood and hardwood kiwifruit stem cuttings were investigated. The PGPR used were Bacillus RC23, Paenibacillus polymyxa RC05, Bacillus subtilis OSU142, Bacillus RC03, Comamonas acidovorans RC41, Bacillus megaterium RC01 and Bacillus simplex RC19. All the bacteria showed indole-3-acetic acid (IAA) producing capacity. Among the PGPR used, the highest rooting ratios were obtained at $47.50 \%$ for semi-hardwood stem cuttings from Bacillus RC03 and Bacillus simplex RC19 treatments and $42.50 \%$ for hardwood stem cuttings from Bacillus RC03. As well, Comamonas acidovorans RC41 inoculations indicated higher value than control treatments. The results suggest that these PGPR can be used in organic nursery material production and point to the feasibility of synthetic auxin (IBA) replacement by organic management based on PGPR.
\end{abstract}

Key terms: PGPR, stem cuttings, kiwifruit, rooting, auxin

\section{INTRODUCTION}

Kiwifruit are utilized almost exclusively as fresh fruits, with the exception of a small proportion juiced and mixed with other juices and used in wine coolers. The plant also has an ornamental value (1).

Kiwifruit was first introduced to Turkey in the $1980 \mathrm{~s}$. In the last few years significant progress has been achieved. Several experiments have been conducted in different agro-ecological areas; mainly in the Black Sea, Marmara, Aegean and Mediterranean regions, and considerable information has been collected on plantclimate and plant-soil relations and the area for kiwifruit cultivation in Turkey is expanding (2). Interest in self-rooting kiwifruit plants has increased, especially in some regions of Turkey where winterdamaged trunks can be replaced more rapidly from adventitious shoots. The demand for these plants has led nursery operators to look for effective means of propagating large number of plants rapidly. More recently, organic kiwifruit production has also gained importance in Turkey and there is increased interest among farmers in nursery materials for organically producued kiwifruit.

Kiwifruit may be propagated by various methods, such as grafting seedlings, stem cuttings, root cuttings and tissue culture (3). The most rapid and inexpensive production method of kiwifruit would be of considerable commercial value. Growing cuttings on their own roots could achieve this purpose by eliminating the need for producing rootstocks. Previous research has shown that kiwifruit stem cuttings are characterized by a variable rooting ability $(4,5,6)$. Bench heating, mist, temperature control, growth substance

*Fax: +90 4422360958,*E-mail: yasar_erturk@hotmail.com 
treatments are always required to obtain satisfactory propagation in kiwifruit stem cuttings, making it one of the most difficult species to root $(7,8)$. In addition, the type of cutting and the collecting time have been reported to strongly influence rooting of kiwifruit cuttings $(9,10)$.

PGPR (plant growth promoting bacteria) have gained world wide importance and acceptance. The mechanisms involved in plant growth promotion by PGPR involve direct and indirect effects. Direct effects occur when PGPR produces substances such as phytohormones. These microorganisms are the potential tools for sustainable agriculture and the trend for future $(11,12,13,14)$. Recent studies confirm that the treatments of seeds or cuttings with non-pathogen bacteria, such as Agrobacterium, Bacillus, Streptomyces, Pseudomonas, Alcaligenes etc. induced root formation in some plants because of natural auxin production of bacteria $(14,15,16,17,18)$. Although, the mechanisms are not completely understood, root induction by PGPR is the accepted result of phytohormones, such as auxin production, inhibition of ethylene synthesis and mineralization of nutrients by PGPR $(18,19)$. Considering the numerous interactions between the different hormonal signaling pathways in plants, it is difficult to assess which of these pathways is the primary target of PGPR. More likely, PGPR alters several, hormonal pathways. This could account for the different morphological changes observed, for example, lateral root elongation and root hair development. One of the more characteristic effects of PGPR is an increased elongation rate, and perhaps initiation rate, of lateral roots resulting in more branched root system architecture $(20,21)$.

Environmentally friendly applications in agriculture have gained more importance, in particular in horticulture and nursery production. The use of PGPR for nursery material multiplication may be important for obtaining organic nursery material because the use of all formulations of synthetic plant growth regulators, such as indole-3-butyric acid (IBA), is prohibited in organic agriculture throughout the world.

The aim of this study was to determine the effects of PGPR strains, Bacillus RC23,
Paenibacillus polymyxa RC05, Bacillus subtilis OSU 142, Bacillus RC03, Comamonas acidovorans RC41, Bacillus megaterium $\mathrm{RC} 01$ and Bacillus simplex RC19 on rooting and root growth in kiwifruit cv. Hayward semi-hardwood and hardwood stem cuttings. In vitro production of indole-3-acetic acid (IAA) by PGPR was also evaluated.

\section{MATERIALS AND METHODS}

Bacterial strains, isolation and identification of bacteria

The PGPR used in this study are given in Table 1. The seven non-pathogenic bacteria, Bacillus RC23, Paenibacillus polymyxa RC05, Bacillus subtilis OSU 142, Bacillus $\mathrm{RC} 03$, Comamonas acidovorans RC41, Bacillus megaterium RC01 and Bacillus simplex RC19 were initially isolated in late summer from the rhizosphere of wild raspberry, wheat and tomato plants in northeastern Turkey, except for Bacillus subtilis OSU 142 from Ohio, USA. The isolation of bacteria was carried out according to Ramos Solano et al. (22). The bacteria were identified based on their whole-cell fatty acid methyl ester (FAMEs) analysis (23) using the MIDI system (Sherlock Microbial Identification System version 4.5, MIDI, Inc., Newark, DE). Bacteria were grown on nutrient agar (NA) for routine use, and maintained in nutrient broth (NB) with $15 \%$ glycerol at $-80^{\circ} \mathrm{C}$ for long-term storage. For each experiment, a single colony was transferred to $500 \mathrm{ml}$ flasks containing NB, and grown aerobically in flasks on a rotating shaker $(150 \mathrm{rpm})$ for $48 \mathrm{~h}$ at $27^{\circ} \mathrm{C}$ (Merck KGaA, Germany). The bacterial suspension was then diluted in sterile distilled water to a final concentration

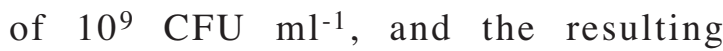
suspensions used to treat kiwifruit cuttings.

\section{Quantification of IAA production of bacteria}

The bacteria were also tested for indole-3acetic acid (IAA) production, using the method of Bent et al. (24). The flasks were 
incubated for $18 \mathrm{~h}$ at $27^{\circ} \mathrm{C}$ with $100 \mathrm{rpm}$ rotary shaking. Following this, $125 \mathrm{ml}$ flasks containing $40 \mathrm{~mL}$ half-strength TSB, supplemented with $0,0.1$, and $25 \mathrm{mg}$ tryptophan $\mathrm{ml}^{-1}$ were each inoculated with $1 \mathrm{ml}$ of each strain. After incubation for 48 , 72 , and $168 \mathrm{~h}$, the density of each culture was measured spectrophotometrically at $600 \mathrm{~nm}$, and then the bacterial cells were removed from the culture medium by centrifugation. The level of indoles present in the culture fluid was estimated colorimetrically. The concentration of IAA in the bacterial eluates was measured by using Salkowski's reagent $(50 \mathrm{~mL} 35 \%$ $\mathrm{HClO}_{4}+1 \mathrm{~mL} \mathrm{FeCl}_{3}$ ). Each reaction mixture was centrifuged. The absorbance at $530 \mathrm{~nm}$ in a Shimadzu Spectrophotometer UV-1208 was measured. Bacterial cells were separated from the supernatant by centrifugation at $10,000 \mathrm{rpm}$ for $30 \mathrm{~min}$. The concentration of IAA in each culture medium was determined by comparison with a standard curve. The IAA produced by each strain was measured in triplicate. Besides, after 48, 72, and $168 \mathrm{~h}$ of growth, samples were taken for determination of IAA by thin-layer chromatography (TLC) and high performance liquid chromatography-mass spectrometry (HPLC-MS) analysis. Separation of indole in ethyl-acetate fraction was carried out in chloroform-ethyl acetate-formic acid.

\section{Plant materials}

Semi hardwood and hardwood stem cuttings of kiwifruit cv. Hayward were prepared from middle parts of vigorous shoots of 14-yr-old plants during June and January in both 2006 and 2007. The cuttings had three buds and were $20 \mathrm{~cm}$ in height and $1 \mathrm{~cm}$ in diameter. Bacterial treatments were performed by dipping the cuttings into the bacterial suspension prepared in sterile water at the concentration of $10^{9} \mathrm{cfu} \mathrm{ml}^{-1}$ for $30 \mathrm{~min}$. Cuttings in the control group were treated with sterile water. For IBA treatments, the basal portion of cuttings was dipped in an aqueous solution of either 2000 or 4000 ppm IBA (50\% ethanol) for $5 \mathrm{~min}$, and allowed to air dry. Following treatments, cuttings were placed in trays filled with perlite media to a depth of $10 \mathrm{~cm}$ under mist (15 s/6 min) in a greenhouse maintained at $21 \pm 2{ }^{0} \mathrm{C}$. The data were obtained after 3 months. The evaluated parameters determined by Orhan et al. (25) were rooting percentage, the number of main roots per cutting, the highest root length $(\mathrm{cm})$, average root diameter $(\mathrm{mm})$, root dry weight per cutting $(\mathrm{mg})$ and root quality (1-5 scale).

\section{Data Analysis}

The experimental design used was a randomized complete block with 4 replications. Each replication contained 10 cuttings spaced $50 \mathrm{~mm}$ apart. Data were subjected to analysis of variance using ANOVA and means were separated by Duncan's multiple range tests $(\mathrm{p}<0.05)$. There were no statistical differences between years, therefore the data were pooled.

TABLE 1

The bacterial strains, codes and sources

\begin{tabular}{lccc}
\hline Bacterial strains & Code & Characteristics & Sources \\
\hline Bacillus $\mathrm{RC} 23$ & $\mathrm{RC} 23$ & IAA producing capacity & Wild raspberry \\
Paenibacillus polymyxa $\mathrm{RC} 05$ & $\mathrm{RC} 05$ & $\mathrm{~N}_{2}$ fixing + IAA producing capacity & Wheat \\
Bacillus subtilis & $\mathrm{OSU} 142$ & $\mathrm{~N}_{2}$ fixing + IAA producing capacity & Tomato \\
Bacillus RC03 & $\mathrm{RC} 03$ & IAA producing capacity & Wheat \\
Comamonas acidovorans $\mathrm{RC} 41$ & $\mathrm{RC} 41$ & IAA producing capacity & Wild raspberry \\
Bacillus megaterium RC01 & $\mathrm{RC} 01$ & IAA producing capacity & Wheat \\
Bacillus simplex $\mathrm{RC} 19$ & $\mathrm{RC} 19$ & IAA producing capacity & Wild raspberry \\
\hline
\end{tabular}


RESULTS AND DISCUSSION

\section{IAA production of bacteria}

Great variation was observed in the IAA production capacity among PGPR tested $(p<0.05)$ (Table 2). All inoculated strains of PGPR were able to produce plant growthpromoting phytohormone, IAA (indole-3acetic acid) (Table 2), affirming the natural ability of PGPR in synthesizing IAA. The amount of IAA produced varied among the bacteria, ranging from 4.3 (Bacillus RC23) to $7.2 \mu \mathrm{g}$ (Bacillus simplex $\mathrm{RC} 19$ ) in the absence of tryptophan supplements. However, when seven strains were grown in the presence of $25 \mu \mathrm{g}$ of tryptophan per $\mathrm{ml}$ for approximately $48-168 \mathrm{~h}$, the tested PGPR responded by producing higher levels of IAA. Bacillus simplex RC19 and Paenibacillus polymyxa RC05 produced higher levels of IAA (33.6 and $32.8 \mu \mathrm{gml}^{-1}$ $\left.\left(\mathrm{OD}_{600} \text { unit }\right)^{-1}\right)$, while the lowest IAA production was detected from Bacillus RC23 (20.4 gmml $\left.^{-1}\left(\mathrm{OD}_{600} \text { unit) }\right)^{-1}\right)$ (Table 2). Many micro organisms that interact with plants can synthesize hormones similar to those produced by the plant as growth regulator, such as auxins, gibberellins and cytokines (26). Among them, auxin is one of the most well-known phytohormones because of its important role in the initial processes of lateral and adventitious root formation (27) and root elongation (28).
Our results showed that PGPR produce auxin themselves and may also affect auxin synthesis of cuttings (29). IAA is the most commonly produced auxin in nature, synthesized mainly through tryptophan dependent pathways. The endogenous level of IAA in the plant is also important for successful rooting. Furthermore, other indolic compounds, such as indole-pyruvic, indole-acetamide and indole-carboxylicacid, can be involved in root formation (30).

\section{Rooting and root growth of stem cuttings}

The data obtained on the number of main roots per cutting, the highest root length, average root diameter, root dry weight, root quality and rooting percentage for each treatment in kiwifruit semi-hardwood and hardwood stem cuttings are shown in Table 3 and Table 4.

Great variation on all parameters was observed among the PGPR tested in both semi-hardwood and hardwood stem cuttings types $(\mathrm{p}<0.05)$ (Table 3 and 4$)$.

In semi-hardwood cuttings, in terms of induction of roots, the different treatments exhibited varying degrees of response. The PGPR treated semi-hardwood stem cuttings of kiwifruit generally had significantly higher numbers of main roots, root length, root diameter, root dry weight, root quality and rooting percentage than water-treated

TABLE 2

The production of IAA by PGPR in the presence of various concentrations of tryptophan

\begin{tabular}{lcc}
\hline Bacterial strains & \multicolumn{2}{c}{ IAA production $\left(\mu \mathrm{g} \mathrm{ml}^{-1}\left(\mathrm{OD}_{600}\right.\right.$ unit $\left.^{-1}\right)$} \\
\cline { 2 - 3 } & Control & ${\text { Tryptophan }\left(25 \mu \mathrm{g} \mathrm{m}^{-1}\right)}^{2}$ \\
RC23 & $4.3 \pm 0.7 \mathrm{~b}$ & $20.4 \pm 1.6 \mathrm{c}$ \\
RC05 & $6.8 \pm 0.9 \mathrm{ab}$ & $32.8 \pm 2.6 \mathrm{a}$ \\
OSU 142 & $6.3 \pm 0.8 \mathrm{ab}$ & $22.4 \pm 2.1 \mathrm{bc}$ \\
RC03 & $5.9 \pm 0.6 \mathrm{ab}$ & $27.3 \pm 2.7 \mathrm{~b}$ \\
RC41 & $6.7 \pm 0.5 \mathrm{ab}$ & $30.5 \pm 2.4 \mathrm{ab}$ \\
RC01 & $5.6 \pm 0.5 \mathrm{ab}$ & $25.3 \pm 1.7 \mathrm{bc}$ \\
RC19 & $7.2 \pm 0.5 \mathrm{a}$ & $33.6 \pm 2.6 \mathrm{a}$ \\
\hline
\end{tabular}

* Values in the same column with different lower-case letters in same clone are significantly different at $\mathrm{p}<0.05$. Average \pm standard error from three separate experiments. Data were means of three replicates IAA production in average 48,72 , and $168 \mathrm{~h}$ pure cultures. 
control stem cuttings. However, in general these parameters were lower than $2000 \mathrm{ppm}$ and 4000 ppm IBA (indole-3-butyric acid) treatments.

The highest number of main roots per cutting (5.18) was obtained using $4000 \mathrm{ppm}$ IBA followed by 2000 ppm IBA (4.89), Bacillus RC03 (3.40) and Paenibacillus polymyxa RC05 treatments (3.36) (Table 3).

The highest root length and diameter of stem cuttings treated with IBA and bacteria ranged from $9.76 \mathrm{~cm}$ (IBA $4000 \mathrm{ppm}$ ), 9.22 $\mathrm{cm}$ (IBA $2000 \mathrm{ppm}$ ), $8.63 \mathrm{~cm}$ (Bacillus simplex RC19) and $7.70 \mathrm{~cm}$ (Comamonas acidovorans RC41), respectively (Table 3 ).

The best root dry weight (mg) was observed in the $4000 \mathrm{ppm}$ IBA treatment as $22.33 \mathrm{mg}$, while the lowest in control cutting was $2.56 \mathrm{~cm}$ (Table 3 ).

The root quality was the highest in the 4000 ppm IBA treatment (3.33), followed by the 2000 ppm IBA treatment (3.02) and Paenibacillus polymyxa RC05 (2.82). The root quality in control cuttings were the lowest among the treatments (1.63) (Table 3).

The differences in rooting with different treatments were significant, with the highest rooting percentage observed in $4000 \mathrm{ppm}$ IBA, followed by 2000 ppm IBA (57.50\%), and equally $47.50 \%$ in Bacillus RC03 and Bacillus simplex RC19, respectively. The control treatment gave the lowest rooting percentage $(12.50 \%)$ (Table 3 ).

In hardwood stem cuttings, 4000 ppm IBA gave the highest number of main roots (4.74), the greatest root length $(9.11 \mathrm{~cm})$, root diameter $(1.34 \mathrm{~mm})$, root dry weight $(22.11 \mathrm{mg})$, root quality (2.87) and rooting percentage $(65.00 \%)$, respectively (Table 4$)$.

Increases in rooting percentage and root growth of cuttings varied according to PGPR tested. All PGPR increased root growth and rooting percentage over the control. Among PGPR treatments, Bacillus $\mathrm{RC} 03$ were found more effective on the number of main root (3.53) and rooting (42.50\%), Bacillus simplex RC19 on the highest root length $(7.27 \mathrm{~cm})$, Bacillus RC23 on root diameter $(1.22 \mathrm{~mm})$, Paenibacillus polymyxa RC05 on root dry weight (19.32 mg) and root quality (2.44) and Comamonas acidovorans RC41 on rooting $(42.50 \%)$, respectively. Control cuttings gave $0.00 \%$ rooting percentage (Table 4).

These results show that the PGPR treatment is useful for root induction in kiwifruit stem cuttings. Auxin production by bacteria is one of the explanation of

TABLE 3

The effect of bacteria on rooting and root growth of semi-hardwood cuttings of kiwifruit cv. Hayward (Average of 2006 and 2007 years)

\begin{tabular}{lcccccc}
\hline Treatments & $\begin{array}{c}\text { The number } \\
\text { of main roots } \\
\text { per cutting }\end{array}$ & $\begin{array}{c}\text { The highest } \\
\text { root length } \\
(\mathrm{cm})\end{array}$ & $\begin{array}{c}\text { Average root } \\
\text { diameter } \\
(\mathrm{mm})\end{array}$ & $\begin{array}{c}\text { Root dry } \\
\text { weight per } \\
\text { cutting }(\mathrm{mg})\end{array}$ & $\begin{array}{c}\text { Root quality } \\
(1-5 \text { scale })\end{array}$ & $\begin{array}{c}\text { Rooting } \\
(\%)\end{array}$ \\
\hline Control & $0.53 \mathrm{f}$ & $0.70 \mathrm{f}$ & $0.27 \mathrm{e}$ & $2.56 \mathrm{~g}$ & $1.63 \mathrm{e}$ & $12.50 \mathrm{~g}$ \\
IBA 2000 ppm & $4.89 \mathrm{~b}$ & $9.22 \mathrm{ab}$ & $1.18 \mathrm{~b}$ & $19.63 \mathrm{~b}$ & $3.02 \mathrm{~b}$ & $57.50 \mathrm{~b}$ \\
IBA 4000 ppm & $5.18 \mathrm{a}$ & $9.76 \mathrm{a}$ & $1.30 \mathrm{a}$ & $22.33 \mathrm{a}$ & $3.33 \mathrm{a}$ & $72.50 \mathrm{a}$ \\
RC23 & $2.67 \mathrm{~d}$ & $6.73 \mathrm{~cd}$ & $1.05 \mathrm{c}$ & $13.89 \mathrm{e}$ & $2.14 \mathrm{~d}$ & $32.50 \mathrm{e}$ \\
RC05 & $3.36 \mathrm{c}$ & $6.17 \mathrm{de}$ & $1.12 \mathrm{bc}$ & $15.37 \mathrm{~d}$ & $2.82 \mathrm{bc}$ & $40.00 \mathrm{~d}$ \\
OSU142 & $2.47 \mathrm{de}$ & $5.70 \mathrm{de}$ & $0.92 \mathrm{~d}$ & $12.47 \mathrm{f}$ & $2.40 \mathrm{~cd}$ & $25.00 \mathrm{f}$ \\
RC03 & $3.40 \mathrm{c}$ & $6.40 \mathrm{~d}$ & $1.19 \mathrm{~b}$ & $17.18 \mathrm{c}$ & $2.53 \mathrm{c}$ & $47.50 \mathrm{c}$ \\
RC41 & $2.88 \mathrm{~cd}$ & $7.70 \mathrm{c}$ & $1.03 \mathrm{c}$ & $15.76 \mathrm{~d}$ & $1.70 \mathrm{e}$ & $40.00 \mathrm{~d}$ \\
RC01 & $2.47 \mathrm{de}$ & $7.60 \mathrm{~cd}$ & $0.90 \mathrm{~d}$ & $14.86 \mathrm{de}$ & $2.12 \mathrm{~d}$ & $32.50 \mathrm{e}$ \\
RC19 & $3.07 \mathrm{~d}$ & $8.63 \mathrm{ab}$ & $1.13 \mathrm{bc}$ & $17.29 \mathrm{c}$ & $2.00 \mathrm{de}$ & $47.50 \mathrm{c}$ \\
LSD & 0.25 & 1.24 & 0.11 & 1.02 & 0.24 & 4.67 \\
\hline
\end{tabular}

\footnotetext{
* Values in the same column with different lower-case letters are significantly different at $\mathrm{p}<0.05$.
} 
root induction in kiwifruit stem cuttings. Another explanation could be that the cuttings can produce auxin themselves after PGPR inoculation. Unfortunately we did not analyze auxin levels in cuttings during the experiment. The PGPR produced higher percentages of root growth and better quality in terms of root length, diameter, root dry weight etc (Table 3 and Table 4). PGPR is able to exert a beneficial effect on plant growth such as increases in root growth and weight (31). It is evident that the treatment of PGPR on cuttings of different plant species showed genotype dependent rooting and increased root growth $(32,33)$. Patten and Glick (34) reported that IAA producing Pseudomonas putida increased the length of canola seedling roots on average 35 to $50 \%$. Bae et al. (35) stimulated initial development of adventitious roots in cucumber and rose cuttings, using different PGPR isolates. They determined that cucumber seedling cuttings showed various responses to the isolates tested, which is in accordance with our results. Therefore these results could be important for particularly difficult-toroot woody plants, in our case kiwifruit, in order to obtain higher rooting percentages by inoculation with bacteria. McAfee et al. (36) showed that rooting of Pinus was higher when they were inoculated with bacteria strains. Ercisli et al. (37) and Esitken et al. (17) tested PGPR for rooting in rose hip and sour cherry cuttings and found that PGPR were effective to obtain high rooting percentages. Our results support the findings of Ercan et al. (38), who demonstrated that the root numbers increased in Madder (Rubia tinctorum) after PGPR inoculation. Caesar and Burn (39) observed that seedlings of apple gave better lateral roots when treated with PGPR. Kaymak et al. (2008) also demonstrated that mint cuttings inoculated with PGPR resulted in higher rooting percentage and root dry weight.

In conclusion, this study demonstrated that the PGPR belonging to genus Bacillus, Paenibacillus and Comamonas has potential to promote root formation in kiwifruit cuttings in mass clonal propagation. It seems that the stimulation of rooting and root growth by PGPR can be correlated to production of indole-3-acetic acid by the bacteria. In our study in general, the PGPR has higher IAA producing

TABLE 4

The effect of bacteria on rooting and root growth of hardwood cuttings of kiwifruit cv. Hayward (Average of 2006 and 2007 years)

\begin{tabular}{lcccccc}
\hline Treatments & $\begin{array}{c}\text { The number } \\
\text { of main roots } \\
\text { per cutting }\end{array}$ & $\begin{array}{c}\text { The highest } \\
\text { root length } \\
(\mathrm{cm})\end{array}$ & $\begin{array}{c}\text { Average root } \\
\text { diameter } \\
(\mathrm{mm})\end{array}$ & $\begin{array}{c}\text { Root dry } \\
\text { weight }(\mathrm{mg})\end{array}$ & $\begin{array}{c}\text { Root quality } \\
(1-5 \mathrm{scala})\end{array}$ & $\begin{array}{c}\text { Rooting } \\
(\%)\end{array}$ \\
\hline Control & $0.00 \mathrm{~g}$ & $0.00 \mathrm{e}$ & $0.00 \mathrm{~d}$ & $0.00 \mathrm{~g}$ & $0.00 \mathrm{f}$ & $0.00 \mathrm{f}$ \\
IBA 2000 ppm & $4.36 \mathrm{~b}$ & $8.23 \mathrm{ab}$ & $1.28 \mathrm{ab}$ & $18.14 \mathrm{c}$ & $2.71 \mathrm{ab}$ & $50.00 \mathrm{~b}$ \\
IBA 4000 ppm & $4.74 \mathrm{a}$ & $9.11 \mathrm{a}$ & $1.34 \mathrm{a}$ & $22.11 \mathrm{a}$ & $2.87 \mathrm{a}$ & $65.00 \mathrm{a}$ \\
RC23 & $2.47 \mathrm{f}$ & $5.63 \mathrm{~cd}$ & $1.22 \mathrm{ab}$ & $16.25 \mathrm{~d}$ & $2.00 \mathrm{~d}$ & $32.50 \mathrm{de}$ \\
RC05 & $2.87 \mathrm{de}$ & $6.17 \mathrm{c}$ & $1.13 \mathrm{~b}$ & $19.32 \mathrm{~b}$ & $2.44 \mathrm{~b}$ & $35.00 \mathrm{~d}$ \\
OSU142 & $2.67 \mathrm{ef}$ & $5.33 \mathrm{~cd}$ & $1.09 \mathrm{bc}$ & $15.02 \mathrm{e}$ & $2.28 \mathrm{c}$ & $27.50 \mathrm{e}$ \\
RC03 & $3.53 \mathrm{c}$ & $5.03 \mathrm{~d}$ & $1.06 \mathrm{bc}$ & $18.52 \mathrm{bc}$ & $2.42 \mathrm{~b}$ & $42.50 \mathrm{c}$ \\
RC41 & $2.80 \mathrm{e}$ & $6.93 \mathrm{bc}$ & $0.95 \mathrm{c}$ & $14.58 \mathrm{ef}$ & $1.66 \mathrm{e}$ & $42.50 \mathrm{c}$ \\
RC01 & $2.53 \mathrm{ef}$ & $7.07 \mathrm{bc}$ & $1.00 \mathrm{bc}$ & $13.40 \mathrm{f}$ & $2.30 \mathrm{c}$ & $35.00 \mathrm{~d}$ \\
RC19 & $3.13 \mathrm{~d}$ & $7.27 \mathrm{~b}$ & $1.02 \mathrm{bc}$ & $14.57 \mathrm{ef}$ & $2.20 \mathrm{~cd}$ & $40.00 \mathrm{~cd}$ \\
LSD & 0.30 & 1.06 & 0.14 & 1.16 & 0.19 & 7.10 \\
\hline
\end{tabular}

* Values in the same column with different lower-case letters in same clone are significantly different at $\mathrm{p}<0.05$. 
capacity, which also resulted in higher rooting percentages in cuttings. Among PGPR used, as mentioned before, Bacillus RC03, Bacillus simplex RC19 and Comamonas acidovorans RC41 were found to be produce more IAA and these bacteria are also more effective on rooting in kiwifruit stem cuttings, maximizing yield of rooted clonal cuttings in nurseries. As is well-known, the use of chemicals in plant propagation can produce environmental problems and may increase the cost of propagation in nurseries. Therefore, these results can also be important for the use of these PGPR to multiply organic nursery materials. In fact, several commercial PGPR products are already being used in organic agriculture practice. A further topic to analyze is whether the cuttings produce auxin themselves after PGPR treatments.

\section{REFERENCES}

1. ZHENZHEN L, TINGYAO M (1982) Processing of canned Actinidia chinensis. Food Fermented Industry 3: 62-64.

2. BASIM H, UZUN I (2003). Fruit characteristics of kiwifruit in Antalya conditions. Proceedings of National Kiwifruit and Berries Symposium. 23-25 October 2003 Ordu-Turkey. (in Turkish). pp 40-46.

3. LAWES GS (1990) Propagation of kiwifruit. In: Warrington I.J. and Weston G.C. (eds), Kiwifruit: Science and Management. Ray Richards Publisher, $537 \mathrm{p}$.

4. MANFROI V, FRANCISCON AHD, BARRADAS CID, SEIBERT E (1997) Effect of IBA on the rooting and development of kiwifruit cuttings. Ciencia Rural 27(1): 43-46.

5. PANDEY G (1997) Response of IBA, NAA and catechol on rooting of kiwifruit. Journal of Hill Research 10(1): 20-22.

6. RANA HS, RANA VS, BHARDWAJ DR (1999) Vegetative multiplication of kiwifruit (Actinidia deliciosa) through dormant cuttings. Annals of Forestry 7(1): 56-59.

7. BIASI R, MARINO G, COSTA C (1990) Propagation of Hayward (Actinidia deliciosa) from soft and semihardwood cuttings. Acta Horticulturae 282: 243-251.

8 ERCISLI S, ANAPALI O, ESITKEN A, SAHIN U (2002) The effects of IBA, rooting media and cutting collection time on rooting of kiwifruit. Gartenbauwissenschaft 67(1): 34-38

9. SIM BL, LAWES GS (1981) Propagation of kiwifruit from stem cuttings. Gartenbauwissenschaft 46(2): 6568

10. CALDWELL JD, COSTON DC, BROCK KH (1988) Rooting of semi-hardwood 'Hayward' kiwifruit cuttings. HortScience 23(4): 714-717.

11. SIDDIQUI Z (2006) Plant Growth Promoting Bacteria (PGPR). Springer, $318 \mathrm{p}$.

12. DUBEIKOVSKY AN, MORDUKHOVA EA,
KOCHETKOV VV, POLIKARPOVA F Y, BORONIN AM (1993) Growth promotion of blackcurrant softwood cuttings by recombinant strain Pseudomonas fluorescens BSP53a synthesizing an increased amount of indole-3acetic acid. Soil Biology and Biochemistry 25: $1277-1281$

13. JANZEN RA, ROOD SB, DORMAAR JF, McGILL WB (1992) Azospirillum brasilense produces gibberellin in pure culture on chemically-defined medium and in co-culture on straw. Soil Biology and Biochemistry 24: 1061-1064.

14. SRINIVASAN M, PETERSEN DJ, HOLL FB (1996) Influence of indolacetic- acid-producing Bacillus isolates on the nodulation of Phaseolus vulgaris by Rhizobium etli under gnotobiotic conditions. Canadian Journal of Microbiology. 42: 1006-1014.

15. PATENA L, SUTTER EG, DANDEKAR AM (1988) Root induction by Agrobacterium rhizogenes in a difficult-to-root woody species. Acta Horticulturae 227: 324-329.

16. TRIPP KE, STOMP AM (1997) Horticultural applications of Agrobacterium rhizogenes (hairy-root): enhanced rooting of difficult-to-root woody plants. Combined Proceedings of the International Plant Propagators' Society 47: 527-535.

17. ESITKEN A, ERCISLI S, SEVIK I, SAHIN F (2003) Effect of indole-3-butyric acid and different strains of Agrobacterium rubi on adventive root formation from softwood and semi-hardwood wild sour cherry cuttings. Turkish Journal of Agriculture and Forestry 27: 37-42.

18. GOTO M (1990) Fundamentals of Bacterial Plant Pathology. Academic Press. Inc. San Diego, 339 pp

19. STEENHOUDT O, VANDERLEYDEN J (2000) Azospirillum, a free-living nitrogen-fixing bacterium closely associated with grasses: genetic, biochemical and ecological aspect. FEMS Microbiology Reviews 24: 487-506.

20. KAPULNIK Y, OKON Y, HENIS Y (1985) Changes in root morphology of wheat caused by Azospirillum inoculation. Canadian Journal of Microbiology 31: 881-887.

21. LIFSHITZ R, KLOEPPER JW, KOZLOWSKI M, SIMONSON C, CARLSON J, TIPPING EM, ZALESKA I (1987) Growth promotion of canola (rapeseed) seedlings by a strain of Pseudomonas putida under gnotobiotic conditions. Canadian Journal of Microbiology 33: 390-395.

22. RAMOS SOLANO B, PEREYRA DE LA IGLESIA MT, PROBANZA A, LUCAS GARCIA JA, MEGIAS M, MANERO GUTIERREZ FJ (2006). Screening for PGPR to improve growth of Cistus ladanifer seedlings for reforestation of degraded Mediterranean ecosystems. Plant and Soil 287: 59-68.

23. DE FREITAS JR, BANARJEE MR, GERMIDA JJ (1997) Phosphate solubilizing rhizobacteria enhance the growth and yield but not phosphorus uptake of canola (Brassica napus L.). Biology and Fertility of Soils 24: 358-364

24. BENT E, TUZUN S, CHANWAY CP, ENEBAK S (2001) Alterations in plant growth and in root hormone levels of lodge pole pines inoculated with rhizobacteria. Canadian Journal Microbiolgy 47: 793800.

25. ORHAN E, ESITKEN A, ERCISLI S, SAHIN F (2007) Effects of indole 3 butyric acid (IBA), bacteria and radicle tip cutting on lateral root induction in Pistacia vera. Journal of Horticultural Science \& Biotechnology 82 (1): 2-4.

26. MELO IS (1998) Rizobacterias promotoras de crescimento de plantas: descriçao e potencial de uso na 
agricultura. In: Melo, I.S.: Azevedo, J.L. (eds). Ecologia Microbiana. EMBRAPA Meio Ambiente, Jaguariuna, p. 86-116.

27. GASPAR T, KEVERS C, PENEL C, GREPPIN H, REID DM, THORPE TA (1996) Plant hormones and plant growth regulators in plant tissue culture. In vitroPlant Cell Division Biology 32: 272-289.

28. YANG T, LAW DM, DAVIES PJ (1993) Magnitude and kinetics of stem elongation induced by exogenous indole-3-acetic acid in intact light grown pea seedling. Plant Physiology 102: 717-724.

29. GAUDIN V, VRAIN T, JOUANIN L (1994) Bacterial genes modifying hormonal balances in plants. Plant Physiology Biochemistry 32: 11-28.

30. COSTACURTA A, VANDERLEYDEN J (1995) Synthesis of phytohormones by plant-associated bacteria. Critical Reviews Microbiology 21: 1-18.

31. NELSON LM (2004) Plant growth promoting rhizobacteria (PGPR): Prospect for new inoculants. Online. Crop Management doi: 10. 1094/CM-20040301-05-RV.

32. MAFIA RG, ALFENAS AC, MAFFIA LA, FERREIRA EM, SIQUEIRA L (2007) Effect of rhizobacteria on rooting and growth of eucalyptus clones under different conditions of clonal propagation. Revista Arvore 31(5): 813-821.

33. ZHANG Q, LI HB, DUO JG, WANG WF, LIU YQ, LIANG HY, YANG JM (2007) Effect of IBA and Agrobacterium rhizogenes on the softwood cutting of Tilia mandshurica. Acta Horticulturae Sinica 34(1): 201-204
34. PATTEN CL, GLICK BR (2002). Role of Pseudomonas putida indole acetic acid in development of the host plant root system. Applied Environmenal Microbiology 68: 3795-3801.

35. BAE YS, PARK K, LEE YG, CHOI OH (2007) A simple and rapid method for functional analysis of plant growth promoting rhizobacteria using the development of cucumber adventitious root system. Plant Pathology Journal 23(3): 223-225.

36. McAFEE BJ, WHITE EE, PELCHER LE, LAPP MS (1993) Root induction in Pine (Pinus) and Larch (Larix) spp. using Agrobacterium rhizogenes. Plant Cell, Tissue and Organ Culture 34: 53-62.

37. ERCISLI S, ESITKEN A, SAHIN F (2004). Exogenous IBA and inoculation with Agrobacterium rubi stimulate adventitious root formation on hardwood stem cuttings of two rose genotypes. HortScience 39 (3): 533-534.

38. ERCAN AG, TASKIN KM, TURGUT K, YUCE S (1999) Agrobacterium rhizogenes-mediated hairy root formation in some Rubia tinctorum L. populations grown in Turkey. Turkish Journal of Botany 23: 373 378.

39. CAESAR AJ, BURN TJ (1987) Growth promoting of apple seedlings and rootstocks by specific strains of bacteria. Phytopathology 77: 1583-1588.

40. KAYMAK HC, YARALI F, GUVENC I, DONMEZ MF (2008) The effect of inoculation with plant growth rhizobacteria (PGPR) on root formation of mint (Mentha piperita L.) cuttings. African Journal of Biotechnology 7(24): 4479-4483. 